\title{
A lunar hygrometer based on plagioclase-melt partitioning of water
}

\section{Y.H. Lin ${ }^{1 *}$, H. Huii, ${ }^{2 *}$, Y. $\mathrm{Li}^{4}$, Y. Xü ${ }^{2}$, W. van Westrenen ${ }^{1 *}$}

Abstract

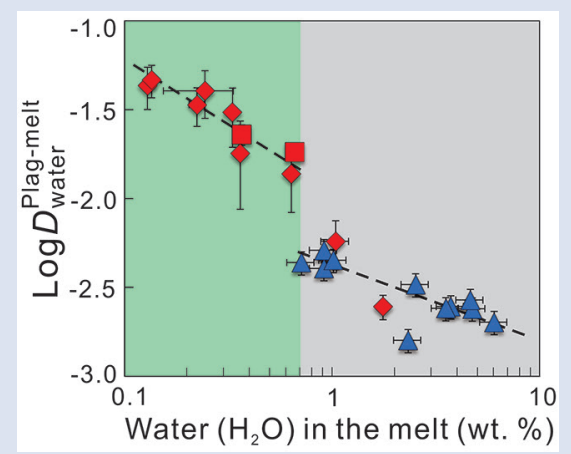

The Moon was initially covered by a magma ocean. Hydrogen detected in plagioclase of ferroan anorthosites, the only available samples directly crystallised from the lunar magma ocean (LMO), can be used to quantify LMO hydrogen content. We performed experiments to determine plagioclase-melt partition coefficients of water under LMO conditions with water contents of co-existing plagioclase and melt quantified using Fourier-Transform Infrared Spectroscopy. Results indicate lunar plagioclase can incorporate approximately one order of magnitude more water than previously assumed. Using measured water contents of lunar plagioclase, this suggests that $\sim 100 \mu \mathrm{g} / \mathrm{g} \mathrm{H} \mathrm{H}_{2} \mathrm{O}$ equivalent was present in the residual magma when $95 \%$ of the initial LMO had crystallised. Our results constrain initial LMO water contents to $\sim 5 \mu \mathrm{g} / \mathrm{g} \mathrm{H}_{2} \mathrm{O}$ equivalent if water was conserved throughout LMO evolution. If on the other hand the initial LMO contained $>1000 \mu \mathrm{g} / \mathrm{g}$ water as suggested by experiments on LMO crystallisation, $>99 \%$ hydrogen degassing occurred during the evolution of the LMO.

Received 5 December 2018 | Accepted 25 February 2019 | Published 26 March 2019

\section{Introduction}

The canonical view of a dry lunar interior has been challenged by detections of hydrogen $(\mathrm{H}$ or $\mathrm{OH}$, reported here as equivalent amounts of $\mathrm{H}_{2} \mathrm{O}$ in $\mu \mathrm{g} / \mathrm{g}$ ) in picritic glass beads (Saal et al., 2008), apatites (e.g., McCubbin et al., 2010; Lin and van Westrenen, 2019), olivine-hosted melt inclusions (e.g., Hauri et al., 2011) and plagioclases (Hui et al., 2013). Sample-based inferences about water in the Moon have been complemented by experimental and modelling studies of lunar magma ocean (LMO) crystallisation (Elkins-Tanton and Grove, 2011; Lin et al., 2017a,b; Charlier et al., 2018; Rapp and Draper, 2018). Quantification of the evolution of the lunar interior volatile budget would provide further insight into the thermal and magmatic evolution of the Moon. However, converting hydrogen abundance data measured in lunar samples or estimated from laboratory experiments to models of the temporal and spatial evolution of water in the Moon, is far from straightforward (McCubbin et al., 2015a).

This study focuses on improving constraints on the water content in the Moon specifically during the LMO stage. Plagioclase is thought to have crystallised and floated to the surface during the late stages of LMO crystallisation, forming the lunar primary feldspathic crust (Warren, 1985).
This indicates that plagioclase in lunar ferroan anorthosite could be our best candidate for estimating the water content of the LMO (Hui et al., 2013, 2017). In addition, plagioclase could have formed continuously from $\sim 70 \%$ all the way up to $>99 \%$ of LMO crystallisation (Lin et al., 2017a; Charlier et al., 2018; Rapp and Draper, 2018). Therefore, the water content of plagioclase formed at different stages during LMO crystallisation could in principle be used to track and quantify the LMO water content through time.

While nominally anhydrous, terrestrial plagioclase can incorporate trace amounts of $\mathrm{H}$ as structural $\mathrm{OH}$ and/ or molecular $\mathrm{H}_{2} \mathrm{O}$. In magmatic feldspars, concentrations from less than a few to more than $1000 \mu \mathrm{g} / \mathrm{g} \mathrm{H}_{2} \mathrm{O}$ have been reported (Johnson and Rossman, 2003, 2004; Johnson, 2006; Mosenfelder et al., 2015). Only very few studies have measured water contents of lunar feldspars from a primary crystallisation product of the LMO so far (Hui et al., 2013; 2017).

To link the water content in plagioclase to that in the melt from which the mineral crystallised, plagioclasemelt partition coefficients $D$ of water are required, with $D_{\text {water }}^{\text {plag-melt }}=C_{\text {water }}^{\text {plag }} / C_{\text {water }}^{\text {melt }}$ Literature values for $D_{\text {water }}^{\text {plag-melt }}$ range between $0.002 \pm 0.0004$ and $0.006 \pm 0.0009$ (recalculated using the plagioclase absorption coefficient determined by Mosenfelder et al. (2015) based on measurements carried out

1. Faculty of Science, Vrije Universiteit Amsterdam, De Boelelaan 1085, 1081 HV Amsterdam, The Netherlands

2. State Key Laboratory for Mineral Deposits Research \& Lunar and Planetary Science Institute, School of Earth Sciences and Engineering, Nanjing University, 163 Xianlin Dadao, Nanjing 210023, China

3. CAS Center for Excellence in Comparative Planetology, Hefei 230026, China

4. Guangzhou Institute of Geochemistry, Chinese Academy of Sciences, 511 Kehua Street, Tianhe District, Guangzhou 510640, China

* Corresponding authors (email: y.lin@vu.nl; hhui@nju.edu.cn; w.van.westrenen@vu.nl) 


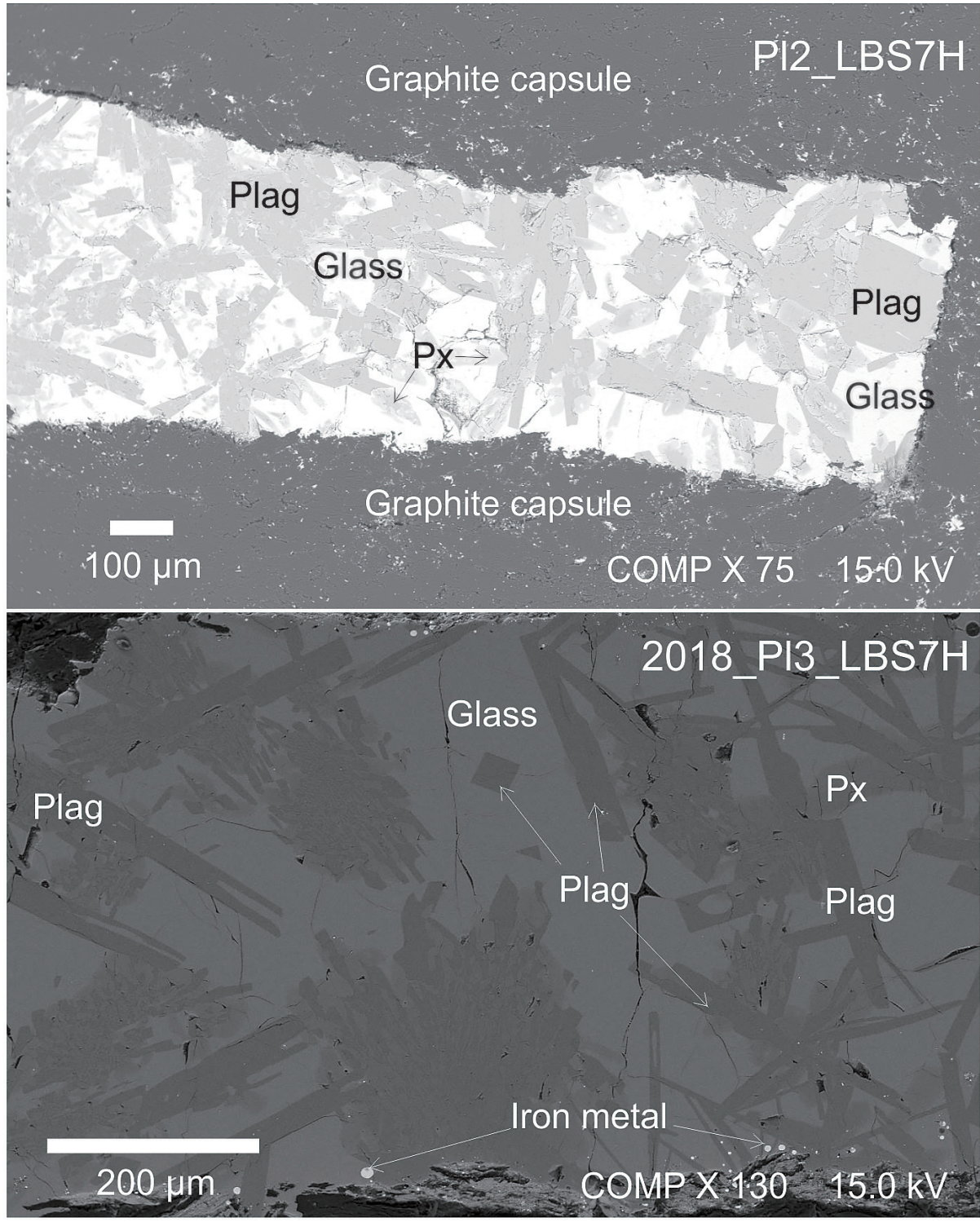

Figure 1 Backscattered electron (BSE) images of representative experimental run products (PI2_LBS7H, $0.4 \mathrm{GPa}-1200{ }^{\circ} \mathrm{C}$; and 2018_PI3_LBS7H, $\left.0.3 \mathrm{GPa}-1160^{\circ} \mathrm{C}\right)$. Px = pyroxene; Plag = plagioclase

in both natural and experimental systems, which have focused solely on magmatism on Earth (e.g., Hamada et al., 2013). To date, no plagioclase-melt partition coefficient of water under lunar conditions has been published. This is problematic, for example in terms of oxygen fugacity, as it has previously been suggested that $\mathrm{fO}_{2}$ can affect hydrogen solubility in plagioclase (Yang, 2012). The available $D_{\text {water }}^{\text {plag-melt }}$ data, which are applied to terrestrial systems, were obtained at relatively oxidising conditions. The $\mathrm{fO}_{2}$ in the Moon is thought to be significantly lower, at IW to IW-2 (IW: iron-wustite) (Sato et al., 1973; Rutherford and Papale, 2009) based on sample analyses. In addition, although Yang (2012) suggests plagioclase composition, temperature and pressure have insignificant effects on $D_{\text {water }}^{\text {plag-melt }}$, this suggestion was based on experiments conducted in a limited temperature-pressure range.

In this study, $D_{\text {water }}^{\text {plag-melt }}$ was determined at pressure-temperature-composition conditions occurring in the lunar magma ocean using high pressure and high temperature experiments and Fourier-Transform Infrared Spectroscopy (FTIR). The pressures (0.4-0.6 GPa) and temperatures (1130-1220 ${ }^{\circ} \mathrm{C}$ ) were chosen to be consistent with plagioclase formation during crystallisation of a water-bearing lunar magma ocean (Lin et al., 2017a). The main purposes of this paper are: (1) to quantify the effects of composition and $\mathrm{fO}_{2}$ on $D_{\text {water }}^{\text {plag-melt }}$, and (2) to offer further constraints on the water content of the LMO at the time of plagioclase crystallisation.

\section{Water Partition Coefficients}

Details of high pressure, high temperature, plagioclase-melt partitioning experiments are given in the Supplementary Information. Table 1 provides a summary of experimental $P-T-\mathrm{fO}_{2}$ conditions. Starting compositions, EMPA analyses of the major element concentrations in plagioclase and melt phases in the experimental run products, and $\log \left(\mathrm{fO}_{2}\right)$ calculations are shown in Tables S-1 and S-2 of the Supplementary Information. All experimental charges contain plagioclase, pyroxene, and quenched glass (Fig. 1). One experimental charge contains Fe metal in addition, indicating an oxygen fugacity at or below that of the iron-wüstite buffer. Representative unpolarised FTIR spectra of plagioclase are shown in Figure 2. All plagioclases show absorption bands ( 3000$3600 \mathrm{~cm}^{-1}$ ) in the mid-infrared region typical of $\mathrm{O}-\mathrm{H}$ bonds (Johnson and Rossman, 2004). No $\mathrm{H}_{2}$ bands have been observed in our plagioclase spectra. Further descriptions are shown in the Supplementary Information. 
Table 1 gives FTIR-derived $\mathrm{H}_{2} \mathrm{O}$ concentrations in plagioclase and glass from our work, Hamada et al. (2013) and Caseres et al. (2017). The $\mathrm{H}_{2} \mathrm{O}$ equivalent concentrations in our samples range from $42 \pm 6$ to $99 \pm 36 \mu \mathrm{g} / \mathrm{g}$ in plagioclase and $0.13 \pm 0.01$ to $1.74 \pm 0.01$ wt. \% in silicate glass. The corresponding partition coefficients range between $0.0020 \pm 0.0004$ and $0.0460 \pm 0.0096$.

The $\mathrm{H}_{2} \mathrm{O}$ concentrations in our plagioclase crystals are significantly below water solubility at our experimental conditions (Yang, 2012). Sample 2018_Pl17_LBS8H, with glass containing the highest water concentration (1.74 wt. \% $\mathrm{H}_{2} \mathrm{O}$ ), has the lowest water concentration in plagioclase $\left(42 \mu \mathrm{g} / \mathrm{g} \mathrm{H}_{2} \mathrm{O}\right)$ and hence the lowest partition coefficient $\left(D_{\text {water }}^{\text {plag-mit }}=0.0020 \pm 0.0004\right)$. This lowest value is at the lower end of the range of previously published partition coefficients $\left(D_{\text {water }}^{\text {plag-melt }}=0.002-0.006\right)$ by Hamada et al. (2013). Our highest partition coefficient is $\sim 7-20$ times higher than values from the Hamada et al. (2013) data set. The water partition coefficients reported by Caseres et al. $\left(2017 ; D_{\text {water }}^{\text {plag-melt }}=0.018-0.023\right.$ at the IW buffer) overlap with our results.

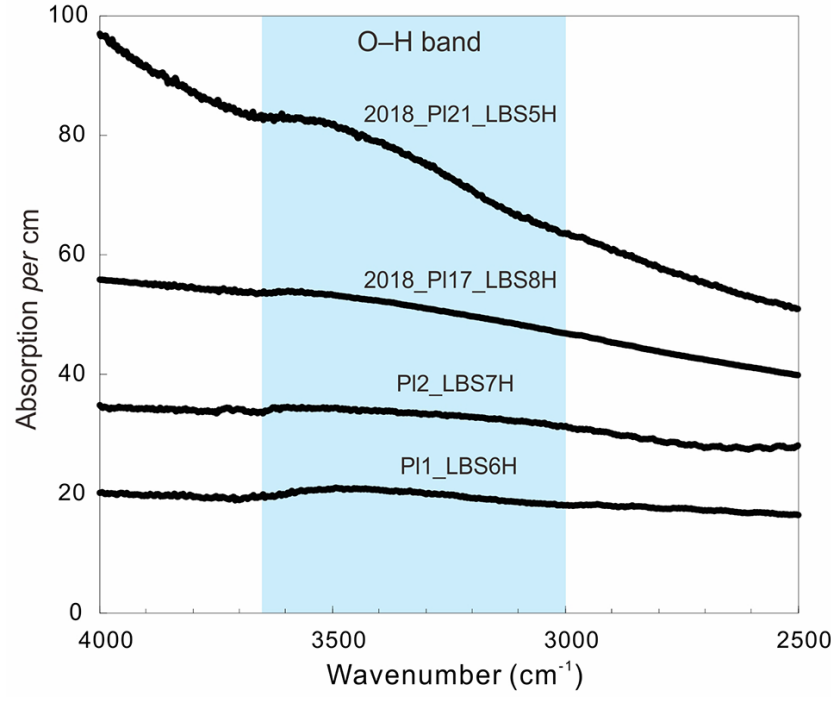

Figure 2 Representative unpolarised infrared spectra of plagioclase, normalised to $1 \mathrm{~cm}$ thickness. Spectra are shifted vertically to facilitate comparison.

Table 1 Summary of experimental conditions and water contents of run products in our experiments and literature data.

\begin{tabular}{|c|c|c|c|c|c|c|c|c|c|c|c|c|c|}
\hline \multirow{2}{*}{ Sample } & \multicolumn{3}{|c|}{ Conditions } & \multicolumn{3}{|c|}{ Plagioclase } & \multicolumn{3}{|c|}{ Glass } & \multicolumn{2}{|c|}{$\begin{array}{l}\text { Water partition } \\
\text { coefficient }\end{array}$} & \multicolumn{2}{|c|}{ Oxygen fugacity } \\
\hline & $\begin{array}{c}\mathrm{P} \\
(\mathrm{GPa})\end{array}$ & $\mathrm{T}^{\circ} \mathrm{C}$ & $\begin{array}{c}\text { Duration } \\
\text { (h) }\end{array}$ & $\mid \begin{array}{c}\mathrm{OH}(\mu \mathrm{g} / \mathrm{g} \\
\left.\mathrm{H}_{2} \mathrm{O}\right)\end{array}$ & $\mathrm{n}$ & 1 s.d. & $\mid \begin{array}{c}\mathrm{OH}(\mathrm{wt} . \% \\
\left.\mathrm{H}_{2} \mathrm{O}\right)\end{array}$ & $\mathrm{n}$ & 1 s.d. & $D^{\text {plag-melt }}$ & 1 s.d. & Oxygen buffer & $\log \left(f \mathrm{O}_{2}\right)$ \\
\hline \multicolumn{14}{|l|}{ This study } \\
\hline Pl1_LBS6H & 0.4 & 1160 & 14 & 58.2 & 11 & 17.9 & 1.03 & 9 & 0.16 & 0.006 & 0.002 & \multirow{8}{*}{$\begin{array}{l}\text { Graphite-COH } \\
\text { (C-COH) }\end{array}$} & -10.4 \\
\hline Pl2_LBS7H & & 1200 & 16 & 63.2 & 9 & 32.8 & 0.35 & 10 & 0.02 & 0.018 & 0.009 & & -10.0 \\
\hline Pl3_LBS8H_1 & & 1160 & 22 & 96.0 & 4 & 28.8 & 0.24 & 12 & 0.09 & 0.040 & 0.012 & & -10.4 \\
\hline Pl4_LBS8H_2 & & 1180 & 14 & 85.5 & 5 & 33.8 & 0.63 & 8 & 0.04 & 0.014 & 0.005 & & -10.2 \\
\hline Pl5_LBS8H_3 & & 1180 & 18 & 99.1 & 6 & 36.4 & 0.32 & 10 & 0.01 & 0.030 & 0.011 & & -10.2 \\
\hline 2018_Pl2_LBS8H & & 1170 & 24 & 73.4 & 7 & 17.0 & 0.22 & 8 & 0.02 & 0.034 & 0.008 & & -10.3 \\
\hline 2018_Pl17_LBS8H & & 1180 & 24 & 42.2 & 8 & 6.64 & 1.74 & 9 & 0.01 & 0.002 & 0.000 & & -10.2 \\
\hline 2018_Pl21_LBS5H & & 1190 & 24 & 54.2 & 6 & 14.2 & 0.13 & 8 & 0.01 & 0.043 & 0.012 & & -10.1 \\
\hline 2018_Pl3_LBS7H & 0.3 & 1160 & 24 & 61.1 & 7 & 12.602 & 0.13 & 11 & 0.004 & 0.046 & 0.010 & $\begin{array}{l}\text { Iron-Wustite } \\
\text { (IW) }\end{array}$ & -12.4 \\
\hline \multicolumn{14}{|l|}{ Caseres et al. (2017) } \\
\hline $1 \#$ & 0.8 & 1150 & & 82 & & 11 & 0.36 & & 0.003 & 0.023 & 0.003 & Iron-Wustite & -12.3 \\
\hline $2 \#$ & & & & 118 & & 6 & 0.65 & & 0.008 & 0.018 & 0.001 & (IW) & -12.3 \\
\hline \multicolumn{14}{|l|}{ Hamada et al. (2013) } \\
\hline MTL04 & 0.35 & 1130 & 24 & 89.8 & & 13.5 & 3.70 & & 0.56 & 0.002 & 0.000 & \multirow{15}{*}{$\begin{array}{c}>\mathrm{Ni}-\mathrm{NiO} \\
(\mathrm{NNO})\end{array}$} & \multirow{5}{*}{-4.7} \\
\hline MTL05 & & 1170 & 24 & 80.8 & & 12.1 & 2.50 & & 0.38 & 0.003 & 0.000 & & \\
\hline MTL17 & & 1220 & 24 & 35.9 & & 5.4 & 0.90 & & 0.14 & 0.004 & 0.001 & & \\
\hline MTL22 & & 1130 & 24 & 36.0 & & 5.4 & 2.30 & & 0.35 & 0.002 & 0.000 & & \\
\hline MTL26 & & 1160 & 24 & 30.1 & & 4.5 & 0.70 & & 0.11 & 0.004 & 0.001 & & \\
\hline MTL29 & & 1170 & 24 & 45.4 & & 6.8 & 0.90 & & 0.14 & 0.005 & 0.001 & & -5.2 \\
\hline MTL33 & & 1230 & 24 & 44.4 & & 6.7 & 1.00 & & 0.15 & 0.004 & 0.001 & & -5.8 \\
\hline MTL37 & & 1070 & 24 & 111 & & 16.6 & 4.70 & & 0.71 & 0.002 & 0.000 & & -5.2 \\
\hline MTL39 & & 1100 & 24 & 82.9 & & 12.4 & 3.50 & & 0.53 & 0.002 & 0.000 & & \\
\hline MTL40 & & 1100 & 24 & 121 & & 18.2 & 4.60 & & 0.69 & 0.003 & 0.000 & & -4.7 \\
\hline MTL41 & & 1050 & 24 & 119 & & 17.8 & 6.00 & & 0.90 & 0.002 & 0.000 & & \\
\hline \multicolumn{13}{|l|}{ Melt Inclusion } & \\
\hline Pl19-MI & & & & 15.3 & & 2.3 & 0.32 & & 0.05 & 0.005 & 0.001 & & \\
\hline Pl21-MI & & & & 10.6 & & 1.6 & 0.24 & & 0.04 & 0.004 & 0.001 & & \\
\hline Pl22-MI & & & & 16.4 & & 2.5 & 0.26 & & 0.04 & 0.006 & 0.001 & & \\
\hline
\end{tabular}

Note: $\mathrm{n}$, number of analysed plagioclases; s.d., 1 sigma standard deviation; $\log \mathrm{fO}_{2}$ (buffer) corrected in the Supplementary Information;

Melt inclusion data not used in this study because we do not know exact $\mathrm{T}$, $\mathrm{P}$, and whether there was any water loss from the inclusions after formation;

The latest infrared absorption coefficient (Mosenfelder et al., 2015) was used for calibrating water contents of all plagioclases. 


\section{The Effects of Oxygen Fugacity and Water Content in Melt}

It has been shown that a number of parameters can affect water partitioning between nominally anhydrous minerals and silicate melts, including the presence and abundance of chemical impurities and vacancies, the possibility of substitutions with charge-balancing species, temperature, pressure, and oxygen fugacity (e.g., Yang, 2012 and references therein). Previous work on water solubility in feldspar has shown that there is no obvious compositional dependence on the incorporation of $\mathrm{H}$ in the feldspar group except for a possible link with potassium content or sodium-hydrogen diffusion during heating (Yang, 2012; Johnson and Rossman, 2013). Potassium, however, has very low concentrations in ferroan anorthositic plagioclase, <0.03 wt. \% (Dixon and Papike, 1975) and is absent in our experiments. Pressure and temperature effects cannot be assessed on the basis of our experiments, and those of Hamada et al. (2013) and Caseres et al. (2017), due to the overall limited pressure $(0.3-0.8 \mathrm{GPa})$ and temperature $\left(1000-1230{ }^{\circ} \mathrm{C}\right)$ range.

The $\mathrm{H}$ solubility in Fe-poor plagioclase near the IW buffer was demonstrated to be more than twice that determined at more oxidising conditions (Yang, 2012), leading to the hypothesis that oxygen fugacity could cause the difference between data obtained at lunar conditions, including our data and the data of Caseres et al. (2017), and those obtained at terrestrial conditions, i.e. the data of Hamada et al. (2013). However, Figure 3 a shows that there is no correlation between $D_{\text {water }}^{\text {plag-melt }}$ and $\mathrm{fO}_{2}$ in the overall data set. The terrestrial data set at relatively oxidising conditions yields lower $D_{\text {water }}^{\text {plag-melt }}$ than the lunar data sets obtained at lower $\mathrm{fO}_{2}$, similar to the trend between oxygen fugacity and hydrogen solubility in plagioclase (Yang, 2012). One possibility is that the number of vacancies available for hydrogen incorporation is increased at low $\mathrm{fO}_{2}$, for example due to the enhanced incorporation of divalent iron in Al sites (Mosenfelder et al., 2019). However, although high values are found at low $f \mathrm{O}_{2}$, some low- $f \mathrm{O}_{2}$ experiments show low $D_{\text {water }}^{\text {plag-melt }}$ (Fig. 3a). Oxygen fugacity is therefore not the main factor affecting $D_{\text {water }}^{\text {plag-melt }}$. Instead, the experiments suggest that the water content of the silicate melt plays a key role in determining the partition coefficient of water between plagioclase and melt (Fig. 3b). There is an inverse relationship between the measured $D_{\text {water }}^{\text {plag-melt }}$ and the water concentration in silicate melt. In the absence of a theoretical framework to guide the functional form used to describe these inverse relations, we provide the following best-fit equations:

$$
\begin{array}{cc}
D_{\text {water }}^{\text {plag-melt }}=-6 \cdot 10^{-2} \cdot x+0.05\left(x \leq 0.7 ; \mathrm{R}^{2}=0.85\right), & \text { Eq. } 1 \mathrm{a} \\
D_{\text {water }}^{\text {plag-melt }}=-5 \cdot 10^{-4} \cdot x+0.005\left(x>0.7 ; \mathrm{R}^{2}=0.60\right), & \text { Eq. } 1 \mathrm{~b}
\end{array}
$$

where $x$ is wt. $\% \mathrm{H}_{2} \mathrm{O}$ in the silicate melt. Equations $1 \mathrm{a}$ and $1 \mathrm{~b}$ provide quantitative estimates of $D_{\text {water }}^{\text {plag-melt }}$ given ranges of the magma oxygen fugacity and water content in silicate melt.

The exact mechanism controlling the observed variations of $D_{\text {water }}^{\text {plag-melt }}$ with $\mathrm{fO}_{2}$ and water content cannot be derived from our experiments, and it is not feasible to construct a thermodynamics-based predictive model of $D_{\text {water }}^{\text {plag-melt }}$ with the currently available data sets. Clearly water partitioning shows strong non-Henrian behaviour in our experiments, pointing to non-ideal behaviour of the relevant hydrogen-bearing species in mineral and/or melt. Previous work has suggested that changes in the $\mathrm{OH}$ site in plagioclases occur as a function of plagioclase $\mathrm{OH}$ content (Hamada et al., 2013), but we cannot identify variations in the shape of the FTIR spectra that would be consistent with such a change in our experiments. It therefore seems more likely that the non-Henrian behaviour is caused by water activity coefficient changes in the melt. The dominant hydrogen-bearing species in hydrous melts at the hydrogen levels in our experiments could be $\mathrm{OH}$ (Stolper, 1982; Newcombe et al., 2017), but non-linear increases in the $\mathrm{H}_{2} \mathrm{O} / \mathrm{OH}$ ratio with increasing silicate melt hydrogen content have previously been observed (Stolper, 1982). These speciation changes affect the $\mathrm{OH}$ activity in the silicate melts, consistent with the observed trend in $D_{\text {water }}^{\text {plag-melt }}$ values, though future work is needed to quantify this correlation.

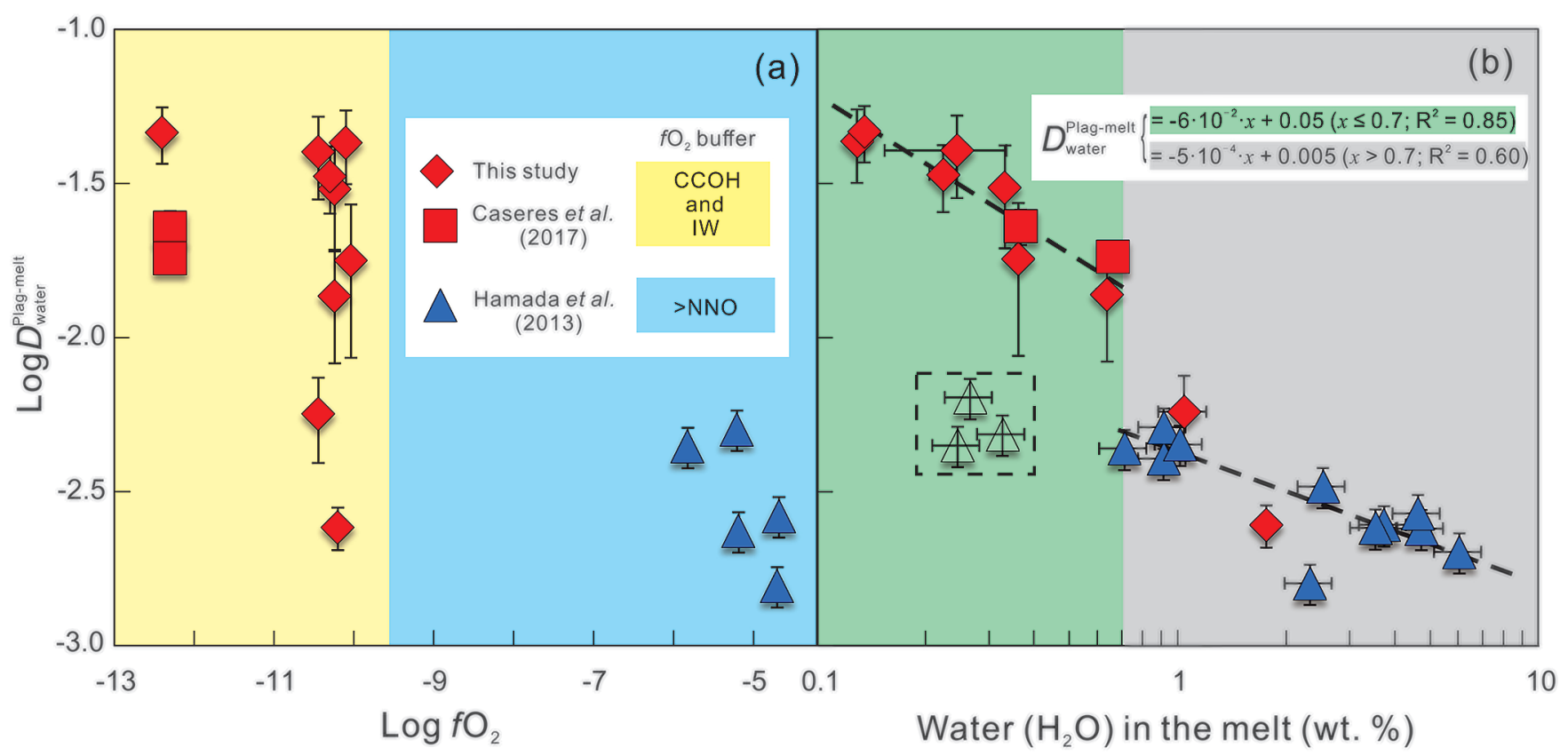

Figure 3 Partition coefficients of water between plagioclase and melt from this study and literature data (Hamada et al., 2013; Caseres et al., 2017), plotted versus (a) oxygen fugacity, and (b) water concentration in silicate melt. Melt inclusion data (Hamada et al., 2013) in the dotted box are not used in this study because the formation temperature of these inclusions and the degree of water loss from inclusions after formation are uncertain. 


\section{Water Content of the Lunar Magma Ocean}

Equation 1a can be used to calculate the water content of the LMO at lunar oxygen fugacity conditions. This calculation requires estimates of (a) the abundance of water in lunar plagioclase, and (b) the degree of crystallisation of the LMO at the time of plagioclase formation.

The latest study published to date on the water content of lunar plagioclase from a primary crystallisation product of the LMO reported $\sim 5 \mu \mathrm{g} / \mathrm{g}$ water $\left(\mathrm{H}_{2} \mathrm{O}\right)$ in ferroan anorthosite samples including Apollo sample 60015 (Hui et al., 2017). We constrained the degree of crystallisation of the LMO when this plagioclase was formed by comparing the $\mathrm{Mg} \#$ (molar $(\mathrm{MgO} /$ $\mathrm{MgO}+\mathrm{FeO}) \times 100)$ of plagioclase from sample $60015(\mathrm{Mg \#}$ of 17-47) (Dixon and Papike, 1975) to the Mg\# of plagioclase formed at different stages from our recent experimental study of LMO crystallisation (Lin et al., 2017a,b). The first plagioclase formed during LMO crystallisation has a Mg\# of $\sim 60$. This $\mathrm{Mg \#}$ decreases with progressive crystallisation. Plagioclase with $\mathrm{Mg \#}$ as low as 17-47 forms after 95 \% crystallisation of the $\mathrm{LMO}$.

Based on the above constraints, the amount of $\mathrm{H}_{2} \mathrm{O}$ equivalent in the residual LMO after $~ 95 \%$ solidification of the initial magma ocean is calculated to be $\sim 100 \mu \mathrm{g} / \mathrm{g}$ by solving the equation $D_{\text {water }}^{\text {plag-melt }}=5 / C_{\text {water }}^{\text {melt }}=-6 \cdot 10^{-2} \cdot\left(C_{\text {water }}^{\text {melt }} / 10000\right)+0.05$ (here, $C_{\text {water }}^{\text {melt }}$ is in $\mu \mathrm{g} / \mathrm{g}$ ). If the LMO hydrogen budget remained constant throughout LMO solidification, this implies a very low initial LMO water content of just $5 \mu \mathrm{g} / \mathrm{g} \mathrm{H}_{2} \mathrm{O}$ equivalent, consistent with inferences from petrology and magma ocean modelling (Elkins-Tanton and Grove, 2011), lunar sample measurements (McCubbin et al., 2015b), and the experimental LMO solidification studies of Rapp and Draper (2018) and Charlier et al. (2018). In contrast, if the initial LMO contained $>500-1800 \mu \mathrm{g} / \mathrm{g}$ water as suggested by the experimental LMO solidification study of Lin et al. (2017a) the minimum amount of water in the residual LMO at the time of lunar plagioclase formation would have exceeded $1 \mathrm{wt}$ \%, far exceeding the $\sim 100 \mu \mathrm{g} / \mathrm{g}$ estimated using the plagioclase hygrometer in this study. In this case, the early Moon experienced extensive degassing, with $>99 \%$ of the initial LMO water budget lost during LMO crystallisation. Such a high degree of degassing is consistent with observations based on the isotopic compositions of hydrogen of lunar plagioclase (Hui et al., 2017) and of chlorine in lunar apatites (Sharp et al., 2010) if degassing of $\mathrm{Cl}$ occurred primarily through metal chlorides (e.g., Schaefer and Fegley, 2004; Sarafian et al., 2017), and would point to a highly dynamic volatile cycle during early lunar evolution.

\section{Acknowledgements}

We dedicate this manuscript to the memory of Erik Hauri. We thank Fei Peng and Wei Chen for technical assistance during electron microprobe analyses and experiments. Dr. Francis McCubbin and Dr. Adam Sarafian are thanked for their constructive reviews, and Dr. Horst R. Marschall is thanked for the editorial handling. This work was supported financially by a Netherlands Organization for Scientific Research (N.W.O.) Vici grant and N.W.O. User Support Programme Space Research grant to WvW, National Natural Science Foundation of China grants (41573055 and 41590623) to HH, Royal Netherlands Academy of Arts and Sciences China Exchange Programme grant (530-6CDP20) to WvW, HH, and YHL, National Natural Science Foundation of China grant (U1530402) to HKM, and partially supported by the Key Research Program of the Chinese Academy of Sciences, Grant NO. XDPB11, Strategic
Priority Research Program (B) of the Chinese Academy of Sciences (XDB18020301) to YL, and Key Research Program of Frontier Sciences (QYZDJ-SSW-DQC012) of the CAS to XX.

Editor: Horst R. Marschall

\section{Author Contributions}

YHL, HH, and WvW. designed this project. YHL. performed the experiments. YJX, YHL, and HH performed the FTIR analyses. YHL wrote the paper with input from all co-authors.

\section{Additional Information}

Supplementary Information accompanies this letter at http:// www.geochemicalperspectivesletters.org/article1908.

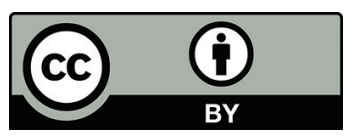

This work is distributed under the Creative Commons Attribution 4.0 License, which permits unrestricted use, distribution, and reproduction in any medium, provided the original author and source are credited. Additional information is available at http://www.geochemicalperspectivesletters.org/copyrightand-permissions.

Cite this letter as: Lin, Y.H., Hui, H., Li, Y., Xu, Y., van Westrenen, W. (2019) A lunar hygrometer based on plagioclase-melt partitioning of water. Geochem. Persp. Let. 10, 14-19.

\section{References}

Caseres, J.R., Mosenfelder, J.L., Hirschmann, M.M. (2017) Partitioning of hydrogen and fluorine between feldspar and melt under the conditions of lunar crust formation. Lunar and Planetary Science Conference 48, 2303.

Charlier, B., Grove, T.L., NAmur, O., Holtz, F. (2018) Crystallization of the lunar magma ocean and the primordial mantle-crust differentiation of the Moon. Geochimica et Cosmochimica Acta 234, 50-69.

DiXON, J.R., PAPIKE, J.J. (1975) Petrology of anorthosites from the Descartes region of the Moon: Apollo 16. Lunar and Planetary Science Conference 6, 263-291.

Elkins-Tanton, L.T., Grove, T.L. (2011) Water (hydrogen) in the lunar mantle: Results from petrology and magma ocean modeling. Earth and Planetary Science Letters 307, 173-179.

Hamada, M., Ushioda, M., Fujil, T., Takahashi, E. (2013) Hydrogen concentration in plagioclase as a hygrometer of arc basaltic melts: Approaches from melt inclusion analyses and hydrous melting experiments. Earth and Planetary Science Letters 365, 253-262.

Hauri, E.H., Weinreich, T., SaAl, A.E., Rutherford, M.C., VAN ORMAN, J.A. (2011) High pre-eruptive water contents preserved in lunar melt inclusions. Science 213, 10-13.

Hui, H., Peslier, A.H., ZHANG, Y., NeAl, C.R. (2013) Water in lunar anorthosites and evidence for a wet early moon. Nature Geoscience 6, 177-180.

Hui H., Guan, Y., Chen, Y., Peslier, A.H., Zhang, Y., LiU, Y., FlemMING, R.L., Rossman, G.R., EILER, J.M., NEAL, C.R., OSINSKI, G.R. (2017) A heterogeneous lunar interior for hydrogen isotopes as revealed by the lunar highlands samples. Earth and Planetary Science Letters $473,14-23$

JOHNSON, E.A. (2006) Water in nominally anhydrous crustal minerals: speciation, concentration, and geologic significance. Reviews in Mineralogy and Geochemistry 62, 117-154.

JOHnSON, E.A., Rossman, G.R. (2003) The concentration and speciation of hydrogen in feldspars using FTIR and ${ }^{1} \mathrm{H}$ MAS NMR spectroscopy. American Mineralogist 88, 901-911.

Johnson, E.A., Rossman, G.R. (2004) A survey of hydrous species and concentrations in igneous feldspars. American Mineralogist 89, 586-600. 
JOHnSON, E.A., Rossman, G.R. (2013) The diffusion behavior of hydrogen in plagioclase feldspar at $800-1000^{\circ} \mathrm{C}$ : Implications for re-equilibration of $\mathrm{OH}$ in volcanic phenocrysts. American Mineralogist 98, 1779-1787.

Lin, Y.H., Tronche, E.J., Steenstra, E.S., van Westrenen, W. (2017a) Evidence for an early wet Moon from experimental crystallization of the lunar magma ocean. Nature Geoscience 10, 14-18.

Lin, Y.H., Tronche, E.J., SteEnStRA, E.S., VAn Westrenen, W. (2017b) Experimental constraints on the solidification of a nominally dry lunar magma ocean. Earth and Planetary Science Letters 471, 104-116.

LIN, Y.H., VAN WESTRENEN, W. (2019) Isotopic evidence for volatile replenishment of the Moon during Late Accretion. National Science Review, doi: 10.1093/nsr/nwz033.

McCubbin, F.M., Steele, A., Hauri, E.H., Nekvasil, H., Yamashita, S., Hemley, R.J. (2010) Nominally hydrous magmatism on the Moon. Proceedings of the National Academy of Sciences of the United States of America 107, 11223-11228.

McCubbin, F.M., Vander KaAden, K.E., Tartèse, R., Boyce, J.W., Mikhail, S., Whitson, E.S., Bell, A.S., Anand, M., Franchi, I.A., WANG, J., HAURI, E.H. (2015a) Experimental investigation of F, $\mathrm{Cl}$, and $\mathrm{OH}$ partitioning between apatite and Fe-rich basaltic melt at 1.0-1.2 GPa and $950-1000{ }^{\circ} \mathrm{C}$. American Mineralogist 100, 1790-1802.

McCubbin, F.M., Vander KaAden, K.E., TArtèse, R., Klima, R.L., LiU, Y., Mortimer, J., Barnes, J., Shearer, C.K., Treiman, A.H. LaWrence, D.J., Elardo, S.M., Hurley, D.M., BoyCe, J.W., ANAND, M. (2015b) Magmatic volatiles (H, C, N, F, S, Cl) in the lunar mantle, crust, and regolith: Abundances, distributions, processes, and reservoirs. American Mineralogist 100, 1668-1707.

Mosenfelder, J.L., Rossman, G.R., JoHnson, E.A. (2015) Hydrous species in feldspars: A reassessment based on FTIR and SIMS. American Mineralogist 100, 1209-1221.

Mosenfelder, J.L., Andrys, J.L., Caseres, J.R., Hirschmann, M.M. (2019) Water in the Moon: The perspective from nominally anhydrous minerals. Lunar and Planetary Science Conference 50, 2132.

Newcombe, M.E., Brett, A., Beckett, J.R., Baker, M.B., Newman, S., GuAn, Y., EILER, J.M., STOLPer, E.M. (2017) Solubility of water in lunar basalt at low $\mathrm{pH}_{2} \mathrm{O}$. Geochimica et Cosmochimica Acta 200, 330-352.

RAPP, J.F., DRAPER, D.S. (2018) Fractional crystallization of the lunar magma ocean: Updating the dominant paradigm. Meteoritics and Planetary Science 53, 1432-1455.

RUtherford, M.J., PAPALE, P. (2009) Origin of basalt fire-fountain eruptions on Earth versus the Moon. Geology 37, 219-222.

SAal, A.E., Hauri, E.H., CAScio, M.L., VAN Orman, J.A., Rutherford, M.C., CoOper, R.F. (2008) Volatile content of lunar volcanic glasses and the presence of water in the Moon's interior. Nature 454, 192-195.

SArafian, A.R., John, T., RoszJar, J., Whitehouse, M.J. (2017) Chlorine and hydrogen degassing in Vesta's magma ocean. Earth and Planetary Science Letters 459, 311-319.

SATO, M., Hickling, N.L., MCLANE, J.E. (1973) Oxygen fugacity values of Apollo 12, 14, and 15 lunar samples and reduced state of lunar magmas. Proceedings of the Lunar Science Conference 1, 1061-1079.

SCHAEFER, L., FegLeY, B. (2004) A thermodynamic model of high temperature lava vaporization on Io. Icarus 169, 216-241.

Sharp, Z.D., Shearer, C.K., McKeEgan, K.D., Barnes, J.D., WANG, Y.Q. (2010) The chlorine isotope composition of the Moon and implications for an anhydrous mantle. Science 329, 1050-1053.

STOLPER, E. (1982) Water in silicate glasses: An infrared spectroscopic study. Contributions to Mineralogy and Petrology 81, 1-17.

WARren, P.H. (1985) The magma ocean concept and lunar evolution. Annual Review of Earth and Planetary Sciences 13, 201-240.

YANG, X. (2012) An experimental study of H solubility in feldspars: Effect of composition, oxygen fugacity, temperature and pressure and implications for crustal processes. Geochimica et Cosmochimica Acta 97, 46-57. 